\title{
Vincristine Sulfate
}

National Cancer Institute

\section{Source}

National Cancer Institute. Vincristine Sulfate. NCI Thesaurus. Code C1739.

The sulfate salt of a natural alkaloid isolated from the plant Catharanthus roseus (Vinca rosea L.) with antimitotic and antineoplastic activities. Vincristine binds irreversibly to microtubules and spindle proteins in S phase of the cell cycle and interferes with the formation of the mitotic spindle, thereby arresting tumor cells in metaphase. This agent also depolymerizes microtubules and may also interfere with amino acid, cyclic AMP, and glutathione metabolism; calmodulin-dependent $\mathrm{Ca}(2+)$-activated AT Pase activity; cellular respiration; and nucleic acid and lipid biosynthesis. 